\title{
Hubungan pengetahuan gizi, tingkat kecukupan zat gizi, dan aktivitas fisik dengan status gizi pada guru SMP
}

\author{
Dinah Soraya*, Dadang Sukandar, Tiurma Sinaga
}

\begin{abstract}
Background: The quality of human resources is a major factor necessary for the successful implementation of national development. Teachers have a very important role in the development of human resources in the field of education. Empirical evidence indicates quality of human resources determined from good nutritional status, and this is determined by nutritional knowledge, the amount of food intake consumed and the physical activity of a person.

Objective: The aim of this study was to analyze the relationship between nutritional knowledge, nutritional adequacy level, and physical activity with nutritional status of teacher in SMPN 1 Dramaga Bogor.

Methods: The research design used was cross sectional with total of 35 subjects. The data collected consist of data individual and family characteristic, nutritional status, food consumption, physical activity, fitness index, sporting habit, nutritional knowledge and general description of the school. The method of this research is most of the subjects (74.3\%) is women with average age classified into middle adult to last adult.

Result: Most of the subjects (68.6\%) was government employee with average working time was 6 to 8 hours. Most of the subjects have nutritional status obesity chategorized (51.4\%). Energy consumption level was classified as medium deficits, protein was low deficits, fats excessive and carbohydrates sufficient. The average level of physical activity on the weekend clasified low, whereas on the weekday classified medium. Most subjects have very low levels of fitness (71.4\%) and their knowledge of nutrition was sufficient $(74.3 \%)$.

Conclusion: There was a significant possitive correlation between work time $(p=0.023, r=0.384)$ and sporting habit with BMI $(p=0.011, r=0.504)$.
\end{abstract}

Keywords: fitness level; nutritional adequacy level; nutritional knowledge; physical activity; teacher

\section{ABSTRAK}

Latar belakang: Kualitas sumber daya manusia merupakan faktor utama yang diperlukan untuk keberhasilan pelaksanaan pembangunan nasional. Guru memiliki peran yang sangat penting dalam pengembangan sumberdaya manusia di bidang pendidikan. Bukti empiris menunjukkan bahwa kualitas sumber daya manusia dapat ditentukan oleh status gizi yang baik, dan status gizi yang baik ditentukan oleh pengetahuan gizi, jumlah asupan pangan yang dikonsumsi dan aktivitas fisik seseorang.

Tujuan: Menganalisis hubungan pengetahuan gizi, tingkat kecukupan zat gizi, dan aktivitas fisik dengan status gizi guru Sekolah Menengah Pertama (SMP) Negeri 1 Dramaga Bogor.

Metode: Desain penelitian yang digunakan adalah cross sectional dengan jumlah subjek 35 orang. Data yang dikumpulkan berupa data karakteristik individu dan keluarga, status gizi, konsumsi pangan, aktivitas fisik, tingkat kebugaran, kebiasaan olahraga, pengetahuan gizi dan gambaran umum sekolah. Metode yang digunakan dalam pengambilan subjek adalah metode sampling jenuh (sensus).

Hasil: Sebagian besar subjek (74,3\%) adalah perempuan dengan rata-rata usia tergolong dewasa tengah hingga dewasa akhir. Sebagian besar subjek (68,6\%) berstatus sebagai Pegawai Negeri Sipil (PNS), jam kerja rata-rata 6 hingga 8 jam. Sebagian besar subjek memiliki status gizi obesitas (51,4\%). Tingkat konsumsi energi tergolong defisit sedang, protein defisit ringan, lemak lebih, dan karbohidrat cukup. Rata-rata tingkat aktivitas fisik subjek pada hari libur ringan dan hari sekolah sedang. Sebagian besar subjek memiliki tingkat kebugaran yang sangat kurang $(71,4 \%)$ dan pengetahuan gizi cukup (74,3\%).

Simpulan: Terdapat hubungan positif antara jam kerja dengan Indeks Massa Tubuh $($ IMT) $(p=0,023, r=0,384)$ dan kebiasaan olahraga dengan IMT ( $p=0,011, r=0,504)$.

Kata kunci: aktivitas fisik; guru; tingkat kecukupan zat gizi; tingkat kebugaran; pengetahuan gizi

\section{PENDAHULUAN}

Tujuan utama pembangunan nasional adalah peningkatan kualitas sumber daya manusia (SDM) yang dilakukan secara berkelanjutan. Kualitas sumber daya manusia merupakan faktor utama yang diperlukan

Program Studi Ilmu Gizi, Fakultas Ekologi Manusia, Institut Pertanian Bogor. Jl. Lingkar Kampus IPB Dramaga, Bogor, 16680, Indonesia;

*Korespondensi: Email: dinahsoraya87@gmail.com untuk keberhasilan pelaksanaan pembangunan nasional. Sumber daya manusia yang berkualitas yaitu individu yang memiliki fisik yang tangguh, mental yang kuat, kesehatan yang prima, serta cerdas. Bukti empiris menunjukkan bahwa hal ini sangat ditentukan oleh status gizi yang baik. Guru mempunyai peranan yang sangat penting dalam pengembangan sumber daya manusia di bidang pendidikan. Sumber daya manusia yang baik dapat mendukung institusi pendidikan untuk berkembang secara optimal 
sebagaimana yang diharapkan. Guru memegang tugas ganda yaitu sebagai pengajar dan pendidik dan memiliki tanggung jawab sebagai tenaga profesional. Pelaksanaan tugas dan tanggung jawab tersebut membutuhkan status gizi yang baik dari seorang guru.

Status gizi dipengaruhi oleh konsumsi pangan dan aktivitas fisik dari seseorang. Konsumsi pangan merupakan faktor utama dalam memenuhi kebutuhan zat gizi di dalam tubuh. Zat gizi berfungsi sebagai sumber tenaga bagi tubuh, mengatur proses metabolisme dalam tubuh, memperbaiki jaringan tubuh serta pertumbuhan. Pemilihan bahan pangan dan penentuan jumlah makanan yang dikonsumsi dipengaruhi oleh pengetahuan gizi. Pengetahuan gizi merupakan aspek kognitif yang menunjukkan pemahaman tentang ilmu gizi, jenis zat gizi, serta interaksinya terhadap status gizi dan kesehatan. Pengetahuan tentang gizi merupakan salah satu hal yang mempengaruhi status gizi secara tidak langsung dan merupakan landasan dalam menentukan konsumsi makanan. ${ }^{1}$

Selain konsumsi pangan, aktivitas fisik juga memiliki peranan penting dalam mencapai SDM yang berkualitas. Aktivitas fisik merupakan gerakan tubuh yang dihasilkan oleh otot rangka dan memerlukan pengeluaran energi. Kurang aktivitas fisik merupakan faktor risiko terkemuka keempat kematian global yang menyebabkan sekitar 3,2 juta kematian. ${ }^{2}$ Secara global sebagian besar kematian disebabkan oleh tekanan darah tinggi (13\%), penggunaan tembakau (9\%), dan kadar glukosa darah yang tinggi $(6 \%)$ disertai oleh aktivitas fisik yang kurang. Proporsi aktivitas fisik tergolong kurang aktif secara umum di Indonesia sebesar 26,1\%. Di Jawa Barat sebesar 20,5\% individu tergolong kurang aktif. ${ }^{3}$ Penurunan aktivitas fisik disebabkan karena banyaknya waktu luang dan perilaku menetap pada pekerjaan dan di rumah.Tingkat aktivitas fisik yang rendah juga disebabkan oleh peningkatan penggunaan alat transportasi. Salah satu indikator untuk menentukan tingkat aktivitas fisik seseorang adalah dengan melihat tingkat kebugaran jasmani. Kebugaran yang dimiliki seseorang akan memberikan pengaruh terhadap kinerja seseorang dan juga akan memberikan dukungan yang positif terhadap produktivitas kerja dan memengaruhi kualitas fisik manusia. ${ }^{4}$

Sebuah penelitian yang melibatkan guru di Semarang menyebutkan bahwa $80,4 \%$ memiliki IMT $\geq 25 \mathrm{~kg} / \mathrm{m}^{2} .{ }^{5}$ Penelitian lain di Medan juga menyebutkan bahwa 48,1\% guru masuk dalam kategori gemuk. ${ }^{6}$ Obesitas pada dewasa yang diduga penyebabnya akibat perubahan gaya hidup, pola makan dan kurangnya aktivitas fisik memicu terjadinya penyakit degeneratif. ${ }^{7}$ Penelitian untuk mengetahui hubungan antara pengetahuan gizi, tingkat kecukupan zat gizi, dan aktivitas fisik dengan status gizi guru di SMP Negeri 1
Dramaga Kabupaten Bogor perlu dilakukan untuk memperkuat hasil-hasil penelitian sebelumnya yang melibatkan guru.

\section{BAHAN DAN METODE}

Desain penelitian ini adalah cross sectional study yang dilakukan pada bulan Maret 2017 di SMP Negeri 1 Dramaga Kecamatan Dramaga, Kabupaten Bogor, Jawa Barat dengan total subjek penelitian sebanyak 35 orang guru. Variabel yang diteliti meliputi pengetahuan gizi, tingkat kecukupan zat gizi, dan aktivitas fisik guru. Data karakteristik subjek dikumpulkan melalui pengisian kuesioner. Data status gizi diperoleh dengan menghitung nilai IMT yang didapat dengan mengukur berat badan dan tinggi badan subjek secara langsung. Data pengetahuan gizi diperoleh melalui kuesioner. Data tingkat kecukupan energi dan zat gizi diperoleh melalui data konsumsi pangan yang didapatkan menggunakan foodrecall $2 \times 24$ jam yang dilakukan pada hari sekolah dan hari libur. Data aktivitas fisik diperoleh melalui recall aktivitas fisik 2x24 jam yang dilakukan pada hari sekolah dan hari libur. Data kebiasaan olahraga dikumpulkan melalui pengisian kuesioner. Data tingkat kebugaran diperoleh melalui uji naik turun bangku menggunakan modifikasi dari metode Harvard Step Test.

Analisis data diawali dengan melakukan uji normalitas Kolmogorov smirnov pada seluruh variabel. Hasil uji normalitas Kolmogorov smirnov menunjukkan bahwa seluruh data variabel yang diuji tidak terdistribusi normal $(\mathrm{p}<0,05)$. Analisis data yang digunakan untuk data yang tidak terdistribusi normal adalah Spearman test (uji hubungan) dan Mann Whitney $U$ (uji beda).

\section{HASIL}

\section{Karakteristik Individu}

Subjek merupakan seluruh guru yang mengajar di SMP Negeri 1 Dramaga dan memenuhi kriteria inklusi. Sebagian besar subjek $(74,3 \%)$ berjenis kelamin perempuan dan berada dalam kategori dewasa tengah $(40 \%)$ dan dewasa akhir $(48,6 \%)$. Usia subjek berkisar antara 25 hingga 58 tahun dengan rata-rata usia $46,3 \pm 10$ tahun. Sebagian besar subjek $(77,1 \%)$ memiliki status sudah menikah. Sebagian besar subjek $(68,6 \%)$ memiliki status kepegawaian sebagai Pegawai Negeri Sipil (PNS). Sebagian besar subjek (80\%) memiliki jam kerja selama 6-8 jam perhari. Sebagian besar subjek $(57,1 \%)$ memiliki masa kerja $>20$ tahun, sebanyak $28,6 \%$ subjek memiliki masa kerja $\leq 10$ tahun, dan $14,3 \%$ subjek memiliki masa kerja 11-20 tahun. 


\section{Karakteristik Keluarga}

Sebagian besar pendapatan perkapita subjek tergolong tidak miskin (97\%) dengan rata-rata pendapatan sebesar Rp 8.084.571,4. Sebagian besar subjek $(60 \%)$ memiliki ukuran keluarga kecil $(\leq 4$ orang) dengan rata-rata $3,8 \pm 2,1$.

\section{Status Gizi}

Status gizi merupakan keadaan tubuh sebagai akibat konsumsi makanan dan penggunaan zat gizi. ${ }^{7}$ Apabila zat gizi dikonsumsi dalam jumlah yang cukup maka kesehatan dapat terjaga, mampu melakukan aktivitas fisik dengan optimal, dan membantu mencegah terjadinya penyakit. Sebaliknya bila zat gizi dikonsumsi dalam jumlah terlalu banyak atau sedikit, maka tubuh akan beradaptasi untuk mencapai keadaan homeostatik sehingga fungsi fisiologis dapat terganggu. ${ }^{7}$ Sebaran subjek berdasarkan status gizi dapat dilihat pada Gambar 1.

Lebih dari separuh subjek $(51,4 \%)$ memiliki status gizi obesitas dengan $31,4 \%$ subjek termasuk kedalam obesitas tingkat I dan $20 \%$ subjek termasuk kategori obesitas tingkat II. Sebanyak 20\% subjek memiliki status gizi overweight. Subjek yang memiliki status gizi normal sebanyak $22,9 \%$ dan sisanya $(5,7 \%)$ memiliki status gizi kurus.

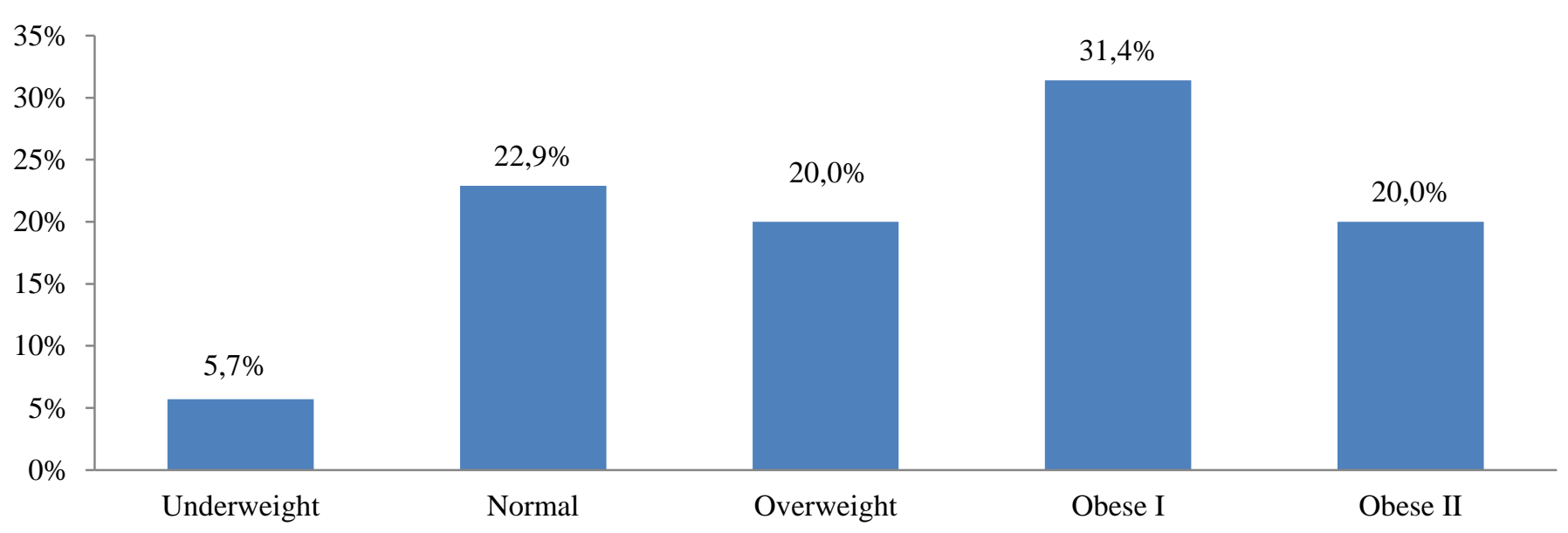

Gambar 1. Karakterisitik Subjek Berdasarkan Status Gizi

\section{Pengetahuan Gizi}

Perilaku yang didasari pengetahuan akan bertahan lebih lama. Oleh sebab itu penting bagi subjek yang memiliki peran ganda sebagai tenaga pendidik di sekolah dan orang tua di rumah untuk memiliki pengetahuan gizi yang baik agar dapat memberikan contoh yang baik dalam kehidupan sehari-hari. Pengetahuan gizi dikategorikan menjadi kurang, sedang dan baik berdasarkan total jawaban benar yang dijawab oleh subjek. Sebaran subjek berdasarkan pengetahuan gizi disajikan dalam Tabel 1 .

Tabel 1. Karakteristik Subjek Berdasarkan Pengetahuan Gizi

\begin{tabular}{lcc}
\hline Pengetahuan gizi & n & \% \\
\hline Kurang & 6 & 17,1 \\
Cukup & 26 & 74,3 \\
Baik & 3 & 8,6 \\
\hline Total & 35 & 100,0 \\
\hline
\end{tabular}

Tabel 1 menjelaskan mengenai sebaran subjek berdasarkan kategori pengetahuan gizi. Sebagian besar subjek memiliki pengetahuan gizi kategori cukup $(74,3 \%)$. Dari 20 pertanyaan mengenai pengetahuan gizi yang diajukan kepada subjek, persentase subjek sudah cukup banyak yang menjawab dengan cukup benar. Terdapat satu pertanyaan yang dijawab dengan benar oleh semua subjek $(100 \%)$ yaitu pertanyaan mengenai fungsi dari zat gizi karbohidrat. Pertanyaan yang paling banyak dijawab secara benar oleh subjek adalah pertanyaan mengenai contoh makanan sumber energi $(88,6 \%)$, akibat dari mengonsumsi makanan sumber energi yang melebihi kebutuhan secara terus menerus $(88,6 \%)$, contoh makanan sumber protein $(91,4 \%)$, akibat dari konsumsi lemak dan minyak secara berlebih $(94,3 \%)$, tanda terjadinya obesitas sentral $(85,7 \%)$, dan bahaya dari kegemukan (86\%).

Pertanyaan yang belum bisa dijawab dengan benar oleh sebagian besar subjek dengan persentase di bawah $60 \%$ yaitu pertanyaan mengenai jumlah pilar yang terdapat dalam pedoman gizi seimbang $(22,9 \%)$, isi pesan dasar yang terdapat dalam pedoman gizi seimbang (34,3\%), akibat kelebihan asupan protein pada saat dewasa $(37,1 \%)$, sumber makanan karbohidrat kompleks $(31,4 \%)$, fungsi vitamin dan mineral (45,7\%), jumlah porsi makanan pokok (karbohidrat) yang dianjurkan untuk dikonsumsi dalam sehari $(14,3 \%)$, dan makanan sumber karbohidrat kompleks $(31,4 \%)$. 


\section{Tingkat Kecukupan Energi dan Zat Gizi}

Tingkat kecukupan energi dan zat gizi diperoleh dengan cara membandingkan asupan energi dan zat gizi dari pangan yang dikonsumsi melalui food recall 2x24 jam dengan kebutuhan gizi setiap subjek. Rata-rata konsumsi dan tingkat kecukupan energi dan zat gizi makro disajikan pada Tabel 2 .

Tabel 2. Rata-Rata Asupan dan Tingkat Kecukupan Energi dan Zat Gizi Makro

\begin{tabular}{lrrr}
\hline Energi dan Zat Gizi & Rata-rata AKG & Rata-rata konsumsi & Rata-rata tingkat kecukupan \\
\hline Energi (kkal) & $2133 \pm 299,0$ & $1646 \pm 443,0$ & $77 \pm 17,0$ \\
Protein (g) & $58,2 \pm 4,5$ & $51,1 \pm 18,9$ & $88 \pm 32,0$ \\
Lemak (g) & $60,9 \pm 10,2$ & $61,9 \pm 12,1$ & $35 \pm 9,0$ \\
Karbohidrat (g) & $316,7 \pm 42,9$ & $220 \pm 18,9$ & $53 \pm 12,0$ \\
\hline
\end{tabular}

Penilaian tingkat kecukupan energi dan zat gizi memerlukan standar kecukupan yang dianjurkan untuk populasi yang diteliti. Rujukan standar yang digunakan di Indonesia adalah dengan menggunakan AKG
(Angka Kecukupan Gizi).Berikut Tabel 3 merupakan sebaran subjek berdasarkan tingkat kecukupan energi dan protein.

Tabel 3. Karakteristik Subjek Berdasarkan Tingkat Kecukupan Energi dan Protein

\begin{tabular}{|c|c|c|c|c|c|c|c|c|c|c|}
\hline \multirow{2}{*}{$\begin{array}{c}\text { Tingkat } \\
\text { Kecukupan }\end{array}$} & \multicolumn{2}{|c|}{ Defisit berat } & \multicolumn{2}{|c|}{ Defisit sedang } & \multicolumn{2}{|c|}{ Defisit ringan } & \multicolumn{2}{|c|}{ Normal } & \multicolumn{2}{|c|}{ Lebih } \\
\hline & $\mathbf{n}$ & $\%$ & n & $\%$ & $\mathbf{n}$ & $\%$ & $\mathbf{n}$ & $\%$ & n & $\%$ \\
\hline Energi & 10 & 28,6 & 7 & 20 & 9 & 25,7 & 9 & 25,7 & 0 & 0,0 \\
\hline Protein & 7 & 20 & 7 & 20 & 8 & 22,9 & 10 & 28,6 & 3 & 8,6 \\
\hline
\end{tabular}

Tingkat kecukupan energi dan protein subjek dibagi menjadi lima kategori, yaitu defisit berat, defisit sedang, defisit ringan, normal, dan lebih. Tabel 4 diketahui bahwa lebih dari separuh subjek $(74,3 \%)$ memiliki tingkat kecukupan energi defisit (tingkat berat, tingkat sedang, dan tingkat ringan). Subjek yang memiliki tingkat konsumsi energi normal hanya 25,7\%. Tingkat kecukupan protein subjek bervariasi dari kategori defisit tingkat berat hingga lebih. Berikut Tabel 4 merupakan sebaran subjek berdasarkan tingkat kecukupan lemak dan karbohidrat.

Tabel 4. Karakteristik Subjek Berdasarkan Tingkat Kecukupan Lemak dan Karbohidrat

\begin{tabular}{ccccccc}
\hline & \multicolumn{2}{c}{ Kurang } & \multicolumn{2}{c}{ Cukup } & \multicolumn{2}{c}{ Lebih } \\
\cline { 2 - 7 } Tingkat Kecukupan & n & \% & n & \% & n & \% \\
\hline Lemak & 0 & 0,0 & 11 & 31,4 & 24 & 68,6 \\
Karbohidrat & 14 & 40,0 & 19 & 54,3 & 2 & 5,7 \\
\hline
\end{tabular}

Lebih dari separuh subjek $(68,6 \%)$ memiliki tingkat kecukupan lemak kategori lebih dan sebagian besar subjek $(54,3 \%)$ memiliki tingkat kecukupan karbohidrat kategori cukup.

\section{Aktivitas Fisik}

Aktivitas fisik subjek pada hari sekolah dibagi menjadi tiga kategori yaitu sangat ringan, dan sedang.Sebaran subjek berdasarkan aktivitas pada hari sekolah dapat dilihat pada Gambar 2.

Lebih dari separuh subjek ketika hari sekolah memiliki tingkat aktivitas fisik ringan $(71,4 \%)$. Hal ini diduga karena sebagian besar jenis kegiatan yang dilakukan oleh subjek di sekolah tergolong kedalam aktivitas ringan (sedentary). Berdasarkan data recall aktivitas fisik pada hari sekolah, sebagian besar waktusubjek pada hari sekolah banyak digunakan untuk mengajar dan duduk untuk mengoreksi tugas siswa.
Recall aktivitas fisik juga dilakukan pada hari libur. Aktivitas fisik subjek pada hari libur dibagi menjadi empatkategori yaitu sangat ringan, ringan, sedang dan berat.Sebaran subjek berdasarkan aktivitas fisik hari libur disajikan pada Gambar 3.

Aktivitas fisik sebagian besar subjek $(51,4 \%)$ tergolong kedalam aktivitas sedang, sebanyak 34,3\% tergolong kedalam aktivitas ringan, dan sisanya tergolong kedalam aktivitas berat (6\%), dan sangat ringan $(8,6 \%)$. Subjek menghabiskan waktu pada hari libur rata-rata untuk tidur $7,1 \mathrm{jam} / \mathrm{hari}$, melakukan kegiatan rumah tangga 6,6 jam/hari, dan bersantai 2,7 jam/hari. Aktivitas fisik subjek dikelompokkan berdasarkan jenis aktivitas fisik. Tabel 5 menunjukkan penyebaran data aktivitas fisik berdasarkan alokasi waktu yang digunakan pada hari libur dan hari sekolah. 


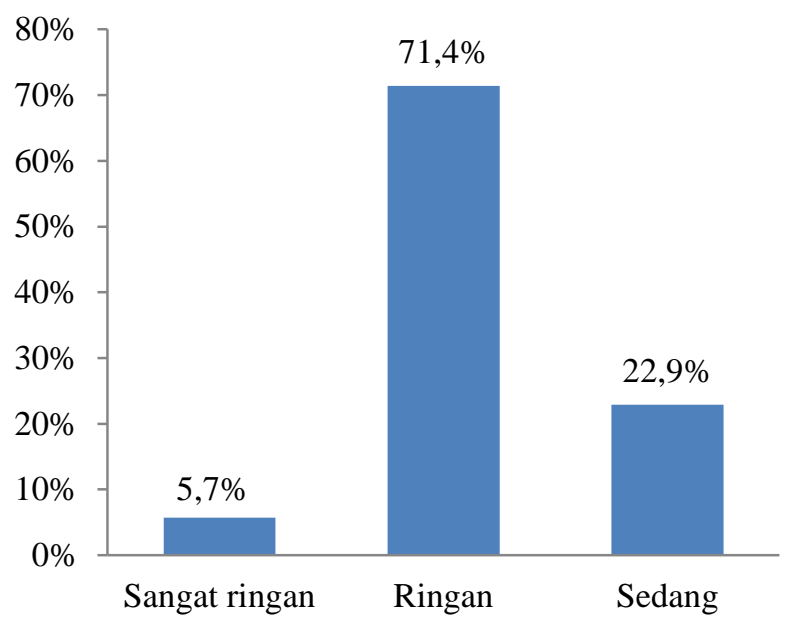

Gambar 2. Karakteristik Subjek Berdasarkan Aktivitas Fisik Hari Sekolah

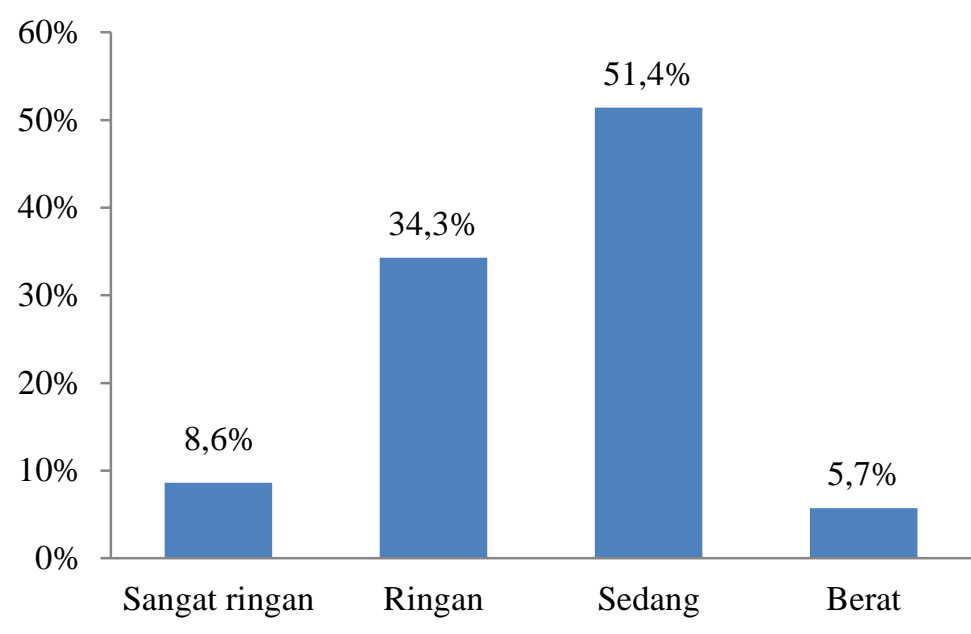

Gambar 3. Karakteristik Subjek Berdasarkan Aktivitas Fisik Hari Libur

Tabel 5. Alokasi Waktu yang Digunakan Subjek pada Hari Libur dan Sekolah

\begin{tabular}{lcc}
\hline \multicolumn{1}{c}{ Kategori aktivitas fisik } & \multicolumn{2}{c}{ Alokasi waktu subjek/hari (\%) } \\
\cline { 2 - 3 } & Hari sekolah & Hari libur \\
\hline Ringan (duduk, berbaring, berdiri, berjalan sekitar, menonton tv, menulis, & $71,2 \%$ & $36,9 \%$ \\
membaca, ngobrol) & & $51,5 \%$ \\
$\begin{array}{l}\text { Sedang (menyuci pakaian, menjemur pakaian, menyapu rumah, menyapu } \\
\text { halaman, mengepel, mengurus anak, belanja, memasak) }\end{array}$ & $20,4 \%$ & $11,6 \%$ \\
$\begin{array}{l}\text { Berat (beternak, berkebun, aktivitas olahraga seperti berenang, bersepeda, } \\
\text { badminton, jogging) }\end{array}$ & $8,4 \%$ & \\
\hline
\end{tabular}

Sebagian besar subjek memiliki aktivitas fisik pada hari sekolah termasuk ke dalam kategori ringan dan pada hari libur tergolong sedang. Hasil penelitian menunjukan rata-rata physical activity level (PAL) subjek yaitu 1,5 $\pm 0,1$ untuk hari sekolah dan 1,7 $\pm 0,2$ untuk hari libur. Hasil ini sesuai dengan hasil uji beda Mann-Whitney terdapat perbedaan $(\mathrm{p}<0,05)$ antara tingkat aktivitas fisik hari libur dengan tingkat aktivitas fisik hari sekolah.

\section{Kebiasaan Olahraga}

Kebiasaan olahraga subjek diamati dalam periode waktu seminggu. Sebaran subjek berdasarkan kebiasaan olahraga dapat dilihat pada Tabel 6.

Tabel 6. Karakteristik Subjek Berdasarkan Kebiasaan Olahraga

\begin{tabular}{lcc}
\hline \multicolumn{1}{c}{ Kebiasaan Olahraga } & n & \% \\
\hline Frekuensi olahraga (per minggu) & & \\
$<1$ kali & 15 & 42,9 \\
$1-2$ kali & 17 & 48,6 \\
$\geq 3$ kali & 3 & 8,6 \\
\hline Total & 35 & 100,0 \\
\hline Durasi olahraga & & \\
$<0$ menit & 15 & 42,9 \\
30 - 60 menit & 17 & 48,6 \\
$>1$ jam & 3 & 8,6 \\
\hline Total & 35 & 100,0 \\
\hline
\end{tabular}

Tabel 6 menunjukkan tidak semua subjek yang menjadi subjek dalam penelitian ini melakukan olahraga setiap minggunya. Terdapat 20 orang subjek $(57,2 \%)$ yang melakukan kegiatan olahraga setiap minggu dan sisanya sebanyak 15 orang subjek atau hampir dari setengah total subjek penelitian $(42,9 \%)$ tidak rutin melakukan kegiatan olahraga setiap minggu.

Sebagian besar subjek $(48,6 \%)$ yang melakukan kegiatan olahraga setiap minggu melakukan kegiatan olahraga 1-2 kali setiap minggu yaitu setiap weekend. Hal ini dikarenakan pada hari weekend subjek dalam kondisi tidak bekerja sehingga waktu tersebut dapat digunakan untuk berolahraga. Durasi olahraga pada sebagian besar subjek $(48,6 \%)$ dilakukan selama 30 hingga 60 menit dan sisanya sebanyak 8,6\% subjek memiliki durasi olahraga lebih dari satu jam. Durasi olahraga dikatakan baik jika total durasi olahraga yang dicapai adalah 30 hingga 60 menit. ${ }^{8}$ Hal ini menunjukkan bahwa durasi olahraga yang dilakukan sebagian besar subjek dikatakan baik.

Jenis olahraga yang dilakukan oleh masingmasing subjek bervariasi. Dari 20 orang subjek yang melakukan olahraga setiap minggunya sebanyak 6 orang $(17,1 \%)$ memilih untuk melakukan jalan pagi. Proporsi yang sama sebesar $8,6 \%$ untuk jenis olahraga bersepeda, badminton, renang, dan senam. Sedangkan terdapat 2 orang $(5,7 \%)$ yang melakukan jogging. 


\section{Tingkat Kebugaran}

Kebugaran jasmani adalah kemampuan tubuh untuk melakukan kegiatan sehari-hari tanpa menimbulkan kelelahan yang berarti. ${ }^{9}$ Sebaran subjek berdasarkan tingkat kebugaran dapat dilihat pada Gambar 4.

Tingkat kebugaran sebagian besar subjek dikategorikan kurang sekali yaitu $71,4 \%$ dan $20 \%$ dengan kategori kurang. Subjek dengan tingkat kebugaran sedang hanya sekitar $8,6 \%$ dan tidak ada satu pun subjek yang memiliki tingkat kebugaran baik dan baik sekali.

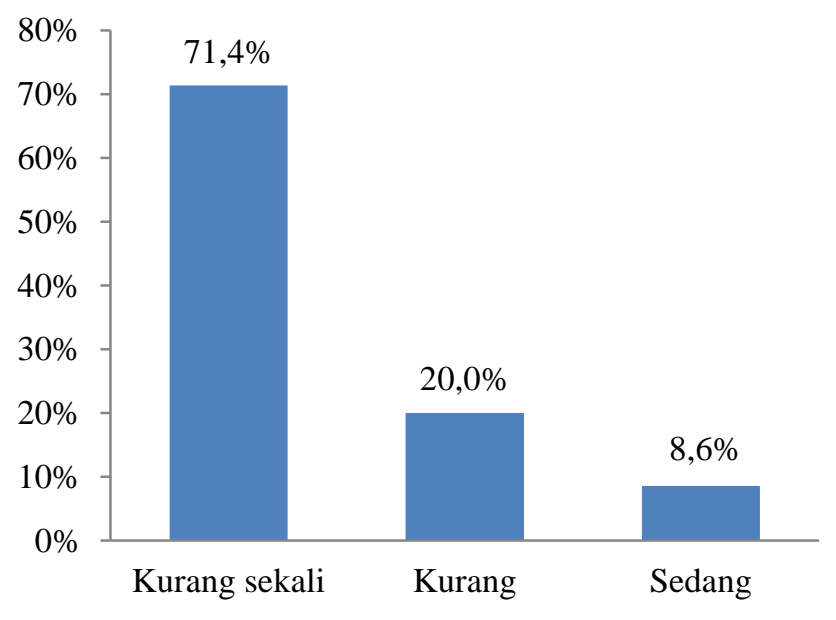

Gambar 4. Karakteristik Subjek Berdasarkan Tingkat Kebugaran

\section{PEMBAHASAN}

\section{Pengetahuan Gizi}

Pengetahuan gizi seseorang berpengaruh terhadap sikap dan perilaku dalam pemilihan makanan yang akhirnya akan berpengaruh pada keadaan gizi individu. Semakin tinggi pengetahuan gizi seseorang diharapkan semakin baik pula keadaan gizinya. ${ }^{3}$ Hasil uji korelasi Spearman menunjukkan tidak terdapat hubungan yang signifikan antara pengetahuan gizi dengan status gizi.

\section{Tingkat Kecukupan Energi dan Zat Gizi}

Hasil uji korelasi Spearman menunjukkan tidak terdapat hubungan yang signifikan antara tingkat kecukupan energi, tingkat kecukupan protein, tingkat kecukupan lemak, dan tingkat kecukupan karbohidrat dengan status gizi. Korelasi negatif antara tingkat kecukupan energi, tingkat kecukupan protein, dan tingkat kecukupan karbohidrat dengan status gizi pada penelitian ini menunjukkan walaupun tidak terdapat hubungan $(p>0,05)$ tetapi memilki kecenderungan adanya hubungan terbalik untuk subjek yang memiliki status gizi lebih tinggi cenderung memiliki tingkat kecukupan energi, protein, dan karbohidrat yang rendah. Tidak terdapat hubungan signifikan kemungkinan dapat disebabkan oleh jumlah subjek yang terlalu sedikit dan tingkat kecukupan subjek cenderung homogen (sebagian besar subjek memiliki tingkat kecukupan energi, protein dan karbohidrat yang tergolong defisit).

Konsumsi pangan pada penelitian ini tidak mencerminkan keseluruhan gambaran status gizi saat ini secara langsung. Hal ini disebabkan karena status gizi merupakan akibat dari konsumsi pangan sebelumnya serta penyakit infeksi yang dideritanya. Konsumsi pangan hanya gambaran bukti sementara dari tingkat kecukupan seseorang dan merupakan konsumsi pada saat diteliti. ${ }^{10}$

\section{Aktivitas Fisik}

Aktivitas fisik merupakan gerakan tubuh yang dihasilkan oleh otot rangka dan membutuhkan energi. ${ }^{2}$ Aktivitas fisik terdiri dari aktivitas selama bekerja, waktu senggang dan aktifias sehari-hari. Sedangkan latihan fisik adalah aktivitas fisik yang direncanakan dan dilakukan dengan terstruktur. ${ }^{4}$ Aktivitas fisik pada umumnya dibagi menjadi tiga golongan yaitu ringan, sedang dan berat. Aktivitas fisik ringan adalah segala sesuatu yang berhubungan dengan menggerakkan tubuh, aktivitas fisik sedang adalah pergerakan tubuh yang menyebabkan pengeluaran tenaga cukup besar, dengan kata lain adalah bergerak yang menyebabkan nafas sedikit lebih cepat dari biasanya, sedangkan aktivitas fisik berat adalah pergerakan tubuh yang menyebabkan pengeluaran tenaga yang cukup banyak (pembakaran kalori) sehingga nafas jauh lebih cepat dari biasanya. ${ }^{2}$

Hasil uji korelasi Spearman menunjukkan tidak terdapat hubungan yang signifikan antara tingkat aktivitas fisik guru pada hari sekolah dengan status gizi. Selama mengajar, subjek memiliki cara mengajar masing-masing. Sebagian besar subjek memilih cara untuk memberikan arahan pelajaran dengan berdiri dan berjalan. Sedangkan hanya sebagian kecil subjek yang memberikan arahan pelajaran dengan cara duduk. Waktu senggang pada hari sekolah banyak dihabiskan untuk istirahat. Subjek menghabiskan waktu pada hari sekolah rata-rata untuk tidur selama $6,1 \mathrm{jam}$ jam/hari, mengajar 6,6 jam/hari, duduk 2,85 jam/hari, dan berkendara $1,5 \mathrm{jam} / \mathrm{hari}$. Hasil penelitian ini sejalan dengan penelitian Nainggolan tahun 2014 yang menunjukkan tidak terdapat hubungan antara aktivitas fisik dengan status gizi.

Hasil uji korelasi Spearman menunjukkan terdapat korelasi negatif antara aktivitas fisik pada hari libur dengan status gizi. Korelasi negatif antara aktivitas fisik pada hari libur dengan status gizi menunjukkan walaupun tidak terdapat hubungan yang signifikan $(p>0,05)$ tetapi memiliki kecenderungan terdapat hubungan terbalik untuk subjek dengan status gizi yang lebih tinggi memiliki aktivitas fisik pada hari 
libur yang cenderung rendah. Tidak terdapat hubungan signifikan kemungkinan dapat disebabkan oleh jumlah subjek yang terlalu sedikit dan aktivitas fisik subjek cenderung homogen $(71,4 \%$ subjek memiliki aktivitas fisik kategori ringan pada hari sekolah dan 51,4\% subjek memiliki aktivitas fisik kategori sedang pada hari libur). Aktivitas yang dilakukan subjek pada hari libur lebih tinggi dibandingkan hari sekolah. Hal ini dikarenakan sebagian besar subjek memiliki jenis kelamin perempuan dimana sebagian besar aktivitas pada hari lubur digunakan untuk melakukan kegiatan rumah tangga. Kegiatan rumah tangga yang dilakukan pada hari libur antara lain menyapu, menyuci pakaian, memasak, belanja, mengepel, dan mengurus anak atau cucu, dan lainnya. Sedangkan untuk subjek yang berjenis kelamin laki-laki pada hari libur banyak yang melakukan kegiatan lain seperti beternak, berkebun, dan memancing.

Peningkatan status gizi berhubungan dengan penurunan aktivitas fisik jangka panjang, dimana antara status gizi dan aktivitas fisik memiliki hubungan yang saling memengaruhi. ${ }^{11}$ Aktivitas fisik mempunyai pengaruh terhadap kejadian obesitas. Semakin sedikit penggunaan waktu untuk melakukan aktivitas sedang dan berat, maka peluang terjadinya obesitas semakin besar. Semakin banyak aktivitas maka semakin banyak kalori yang digunakan sehingga tubuh menjadi ideal atau justru lebih kurus, tetapi apabila kurang beraktivitas tubuh akan cenderung menyimpan kelebihan kalori sehingga terjadi kelebihan berat badan. $^{12}$

\section{Tingkat Kebugaran}

Individu dengan status gizi overweight dan obesitas berhubungan dengan rendahnya tingkat kebugaran. Gambaran tingkat kebugaran jasmani guru pada penelitian ini yaitu tidak ada satu pun guru yang memiliki tingkat kebugaran baik dan baik sekali. Hal ini diduga karena sebagian besar subjek memiliki tingkat konsumsi energi dan karbohidrat yang defisit. Karbohidrat merupakan sumber energi utama bagi tubuh sehingga apabila konsumsi karbohidrat kurang, maka seseorang akankekurangan energi dan merasa lemah sehingga tidak maksimal dalam melakukan aktivitas.

Hasil analisis uji korelasi Spearman menunjukkan tidak terdapat hubungan yang signifikan antara tingkat kebugaran dengan status gizi subjek. Korelasi negatif antara tingkat kebugaran dengan IMT menunjukkan walaupun tidak terdapat hubungan signifikan $(p>0,05)$ tetapi memiliki kecenderungan adanya hubungan terbalik untuk subjek dengan status gizi lebih memiliki tingkat kebugaran yang rendah. Hasil penelitian yang tidak signifikan ini diduga karena adanya beberapa faktor yang memengaruhi tingkat kebugaran pada saat pengambilan data antara lain kecukupan istirahat dan lingkungan sekitar. Kebugaran tubuh dapat dipengaruhi oleh faktor genetik, faktor intensitas latihan individu, usia, jenis kelamin, dan kebiasaan merokok. ${ }^{13}$ Seseorang dengan status gizi overweight dan obesitas berhubungan dengan rendahnya tingkat kebugaran. Terdapat hubungan negatif antara kegemukan dengan tingkat kebugaran. ${ }^{14,15}$

\section{Kebiasaan Olahraga}

Rata-rata status gizi guru yang biasa melakukan olahraga adalah obesitas dengan IMT sebesar $27,6 \pm 4,9 \mathrm{~kg} / \mathrm{m}^{2}$. Hubungan antara olahraga dan status gizi dapat dilihat dari frekuensi olahraga yang dilakukan setiap minggu. Hasil uji korelasi Spearman menunjukkan terdapat hubungan yang signifikan antara frekuensi olahraga per minggu dengan status gizi $(\mathrm{p}<0,05)$ yang berarti semakin tinggi frekuensi olahraga maka semakin tinggi status gizi guru.Hal ini dapat disebabkan karena setelah melakukan olahraga, guru merasa lapar yang menyebabkan guru akhirnya makan setelah berolahraga sehingga efek dari olahraga terhadap status gizi tidak nyata.

Setelah berolahraga guru cenderung mengonsumsi cemilan di pinggir jalan dan tinggi lemak. Hal ini dikarenakan jenis olahraga sebagian besar guru adalah jalan pagi, naik sepeda, dan jogging yang dilakukan setiap hari minggu pagi sehingga setelah berolahraga guru memilih untuk membeli makanan yang tersedia di luar rumah. Olahraga mampu merangsang perkembangan otot-otot sehingga berpengaruh terhadap pertumbuhan yang optimal. ${ }^{16}$ Aktivitas fisik dan olahraga diperlukan untuk menjaga berat badan ideal dan kebugaran tubuh. Status gizi akan semakin baik jika disertai dengan olahraga secara teratur dan pola makan gizi seimbang. Namun melakukan olahraga dengan frekuensi terlalu rendah dari kemampuan kondisi tubuh akan menurunkan tingkat kebugaran jasmani.

\section{SIMPULAN}

Berdasarkan uji korelasi Spearman tidak terdapat hubungan antara tingkat pengetahuan gizi, tingkat kecukupan energi dan zat gizi, dan aktivitas fisik dengan status gizi subjek. Akan tetapi terdapat hubungan signifikan positif antara jam kerja dengan status gizi subjek serta kebiasaan olahraga (frekuensi olahraga) dengan status gizi subjek.

\section{DAFTAR PUSTAKA}

1. Khomsan A. Teknik Pengukuran Pengetahuan Gizi. Bogor: Institut Pertanian Bogor; 2000. 
2. World Health Organization. Global Physical Activity Surveillance. Geneva: World Health Organization; 2010.

3. Badan Penelitian dan Pengembangan Kesehatan Kementerian Kesehatan RI. Riset Kesehatan Dasar. Jakarta: Kementerian Kesehatan RI; 2013.

4. Adisapoetra I. Masalah dan Strategi Aktivitas Fisik Masyarakat. Jakarta: Seminar Pra Widyakarya Pangan dan Gizi; 2008.

5. Amelinda RT, Wirawanni Y. Hubungan lingkar leher dan lingkar pinggang dengan kadar trigliserida orang dewasa (studi kasus di SMA negeri 2 Semarang dan SMP Negeri 9 Semarang). Journal of Nutrition College. 2014, 3(4): 647-54.

6. Bakara FS. Pengetahuan Gizi Seimbang, Perilaku Makan dan Status Gizi Guru SMA Negeri 8 Medan Pandau Hulu II Kecamatan Medan Area 2008. [Skripsi]. Medan: Fakultas Kesehatan Masyarakat Universitas Sumatera Utara; 2009.

7. Waloya T, Rimbawan, Andarwulan N. Hubungan antara konsumsi pangan dan aktivitas fisik dengan kadar kolesterol darah pria dan wanita dewasa di Bogor. Jurnal Gizi dan Pangan. 2013, 8(1): 9-16.

8. Giriwijoyo S, Zafar SD. Ilmu Faal Olahraga. Bandung: Fakultas Pendidikan Olahraga dan Kesehatan Universitas Pendidikan Indonesia; 2012.

9. Sulistiono A. Prediksi aktivitas fisik sehari-hari, umur, tinggi, berat badan dan jenis kelamin terhadap kebugaran jasmani siswa SMP di
Banjarmasin. Jurnal Pendidikan dan Kebudayaan. 2014; 20(3): 380-389.

10. Wiardani SG. Konsumsi lemak total, lemak jenuh, dan kolesterol sebagai faktor resiko sindroma metabolik pada masyarakat perkotaan di Denpasar. Jurnal Gizi Klinik Indonesia. 2013; 7(3):121-128.

11. Weiss D, O'loughlin J, Piatt R, Paradis G. 2007. Five-year predictors of physical acyivity decline among adults in low-income communities: a prospevtive study. International Journal of Behavioral Nutrition and Physical Activity. 2007; $4: 2$

12. Simatupang RM. Pengaruh Pola Kosumsi, Aktivitas Fisik dan Keturunan terhadap Kejadian Obesitas Pada Siswa Dasar Swasta di Kecamatan Medan Baru. [Tesis]. Medan: Sekolah Pascasarjana Universitas Sumatera Utara; 2008.

13. Riyadi S. Keperawatan Kesehatan Masyarakat. Jakarta: Salemba Medika; 2007.

14. Setty Prabha, Padmanabha BV, Doddamani BR. Correlation between Obesity and Cardio Respiratory Fitness. International Journal of Medical Science and Public Health. 2013; 2 (2):300-304.

15. Nurdiniyati N. Analisis kualitas konsumsi, status gizi, dan tingkat kebugaran serta hubungannya dengan morbiditas siswa di pesantren. [Skripsi]. Bogor: Institut Pertanian Bogor; 2016.

16. Kurniasih. Landasan Pendidikan Sekolah Dasar. Bandung: Percikan Ilmu; 2010. 